\title{
Peningkatan kerja sama dan hasil belajar ranah CI-C4 siswa pada materi sistem ekskresi manusia melalui model pembelajaran student team achievement division (STAD) di kelas VIII C SMP Negeri 2 Srumbung Magelang
}

\author{
Yuli Kartika ${ }^{1 *}$, Destri Ratna Ma'rifah ${ }^{2}$ \\ Pendidikan Biologi, Fakultas Keguruan dan Ilmu Pendidikan, Universitas Ahmad Dahlan \\ Jl. Jendral Ahmad Yani (Ringroad Selatan) Tamanan, Banguntapan, Bantul \\ Daerah Istimewa Yogyakarta 55191 \\ ${ }^{1}$ kartikayulie99@gmail.com*; ${ }^{2}$ destrirm@pbio.uad.ac.id \\ *korespondensi penulis
}

\begin{abstract}
Abstrak
Penelitian ini dilatarbelakangi oleh permasalahan yang ada di kelas VIII C SMP Negeri 2 Srumbung Magelang yaitu rendahnya kerja sama dan hasil belajar kognitif siswa pada proses pembelajaran IPA Biologi. Penelitian ini bertujuan untuk mengetahui peningkatan hasil belajar kognitif CI-C4 dan kerja sama siswa pada materi sistem ekskresi manusia melalui penerapan model pembelajaran STAD pada siswa kelas VIII C SMP Negeri 2 Srumbung Magelang.

Penelitian ini merupakan Penelitian Tindakan Kelas (PTK) yang dilakukan dalam tiga siklus tindakan. Penelitian ini dilaksanakan pada bulan Maret 2019. Subjek dalam penelitian ini adalah siswa kelas VIII C SMP Negeri 2 Srumbung Magelang semester genap tahun ajaran 2018/2019. Teknik pengumpulan data menggunakan tes dan observasi. Instrumen yang digunakan yaitu soal tes dan lembar observasi. Analisis yang digunakan adalah analisis data deskriptif kuantitatif.

Kerja sama siswa siklus I sebesar 44,92\%, meningkat menjadi 78,05\% pada siklus II, dan meningkat menjadi 90,27\% pada siklus III. Hasil belajar siswa dari hasil tes pada siklus I sebesar $65,21 \%$, meningkat menjadi $83,33 \%$ pada siklus II dan meningkat menjadi $91,66 \%$ pada siklus III. Keterlaksanaan pembelajaran pada siklus I memiliki persentase sebesar $98,44 \%$, pada siklus II dan siklus III meningkat menjadi 100\%. Berdasarkan hasil penelitian diketahui bahwa proses pembelajaran dengan menggunakan model pembelajaran STAD telah berhasil meningkatkan hasil belajar kognitif CI-C4 dan kerja sama siswa pada materi sistem ekskresi manusia dengan 2 siklus tindakan.
\end{abstract}

Kata kunci: Student Team Achievement Division (STAD), Kerja Sama Siswa, Hasil Belajar Ranah CI-C4

\begin{abstract}
This research is initiated because the researcher observed some problems in VII C class of SMP Negeri 2 Srubung Magelang. The researcher reveals that there is a lack in students' team work and cognitive learning result in Biology subject. This research aims to know the improvement of cognitive learning result of CI-C4 as well as students' team work in the material which covers human excretion system using STAD.

This is a classroom action research which is run in three cycles. This research wa started on March 2019. The subject in the research is students in class VIII C of SMP Negeri 2 Srumbung Magelang in even semester of 2018/2019. The data are grathered with test and observation. The research
\end{abstract}


instruments used are test and observation guidelines. The data are then analysed quantitatively.

Students' teamwork in first cycle was $44,92 \%$ and it increased to $78,05 \%$ in the second cycle. It rose open more dramatically to $90,27 \%$ in the third cycle. Meanwhile in terms of learning result, test showed that students' learning result was $65,21 \%$ in the first cycle and improved to around $83,33 \%$ in cycle two. It registered another rise in the third cycle reaching $91,66 \%$. Similarly, learning outcomes in the first cycle was $98,44 \%$ and it improved to $100 \%$ in the second and third cycle. From the data the research can conclude that STAD learning model could successfully improve student' CI-C4 cognitive learning result as well as their teamwork in human excretion system topic only within two cycle.

Keywords: Student Achievement Division (STAD), Students' Team work, C1-C4 Learning Result

\section{PENDAHULUAN}

Kualitas pembelajaran di sekolah sangat ditentukan oleh seorang guru, sebab gurulah yang berperan langsung dalam merencanakan pembelajaran, membimbing dan mengevaluasi hasil belajar siswa di sekolah melalui proses pembelajaran. Selain itu metode, pendekatan dan model pembelajaran yang digunakan oleh guru juga mempengaruhi kualitas pembelajaran di kelas. Keberhasilan pembelajaran dapat dilihat dari hasil belajar para siswa. Hasil belajar adalah pola perbuatan, nilai-nilai, pengertian-pengertian, sikap-sikap, apresiasi dan keterampilan yang diperoleh dari kegiatan belajar (Suprijono, 2014: 5).

Ilmu Pengetahuan Alam (IPA) khususnya Biologi merupakan ilmu yang mengkaji makhluk hidup maupun lingkungannya. Belajar Biologi bukan hanya sekedar penguasaan terhadap berbagai pengetahuan tetapi merupakan suatu proses penemuan yang dapat membangun keterampilan dan memberi pengalaman secara langsung kepada siswa.

Guru dalam proses pembelajaran menggunakan metode ceramah, sehingga menyebabkan siswa melakukan aktivitas sendiri seperti mengobrol dengan temannya dan tidak memperhatikan pada saat guru menjelaskan materi karena siswa merasa bosan dalam pembelajaran. Aktivitas siswa dalam pembelajaran masih kurang, siswa jarang bertanya pada saat pembelajaran, sehingga guru menganggap mereka sudah memahami materi yang diajarkan. Akan tetapi pada saat diberikan ulangan harian siswa mendapatkan nilai yang rendah termasuk pada materi sistem ekskresi manusia. Selain itu dalam kegiatan pembelajaran siswa masih belum terbiasa berdiskusi dengan temannya, siswa yang memiliki kemampuan kognitif yang lebih tinggi cenderung lebih individualis, sehingga keterampilan kerja sama siswa dapat dikatakan belum optimal. 
Karakter kerja sama harus dibentuk sejak dini, hal ini untuk menghindari sifat egois pada diri siswa. Sering terjadi bahwa secara emosional masih banyak siswa yang tidak mau membantu temannya yang mengalami kesulitan dan masih ada siswa yang malu karena dipandang lemah oleh temannya jika ia meminta bantuan (Pratiwi, 2015). Menurut Apriono (2011) kemampuan kerja sama dapat diartikan sebagai kemampuan yang dilakukan oleh beberapa siswa untuk saling membantu satu sama lain sehingga tampak kebersamaan dan kekompakan untuk mencapai tujuan bersama. Kriteria kemampuan kerja sama berdasarkan hasil penelitian Masaavet (2011: 21) adalah memberi informasi sesama anggota kelompok, mampu menyelesaikan perselisihan yang terjadi, menciptakan suasana kerja sama yang akrab, bertukar ide dan pendapat kepada anggota kelompok, mendukung keputusan kelompok, menghargai masukan dan keahlian anggota lain, berpartisipasi melaksanakan tugas dan menghargai hasil kerja kelompok.

Berdasarkan nilai ulangan harian, hasil belajar siswa kelas VIII C SMP Negeri 2 Srumbung Magelang pada tahun ajaran 2017/2018 materi sistem ekskresi manusia memiliki nilai rata-rata yang paling rendah dan belum mencapai Kriteria Ketuntasan Minilamal (KKM) dibandingkan dengan materi yang lain yaitu sebesar 66,22. Hal ini menunjukkan bahwa hasil belajar IPA siswa khususnya pada materi sistem ekskresi manusia masih tergolong rendah.

Melihat permasalahan yang ada di kelas VIII C SMP Negeri 2 Srumbung Magelang perlu adanya upaya peningkatan proses pembelajaran, salah satunya yaitu dengan menerapkan model-model pembelajaran. Melalui penerapan model pembelajaran diharapkan dapat meningkatkan proses pembelajaran yang nantinya dapat meningkatkan hasil belajar dan aktivitas siswa. Salah satu model yang dapat meningkatkan proses pembelajaran, hasil belajar dan aktivitas siswa adalah model pembelajaran kooperatif. Model pembelajaran kooperatif merupakan model pembelajaran yang lebih menekankan proses kerja sama dalam kelompok. Siswa tidak hanya dituntut dalam penguasaan terhadap materi pelajaran saja, tetapi bagaimana siswa dapat kerja sama untuk menguasai materi pelajaran. Salah satu model pembelajaran kooperatif yang dapat diterapkan adalah model pembelajaran Student Team

\section{Achievement Division (STAD).}

Guru memberikan suatu pelajaran dan siswa-siswa di dalam kelompok harus memastikan bahwa semua anggota kelompoknya bisa menguasai pelajaran tersebut. Selanjutnya siswa menjalani kuis secara individu tentang materi tersebut dan pada saat itu mereka tidak boleh saling membantu satu sama lain. Nilai-nilai hasil kuis yang diperoleh siswa secara individu akan dijumlah untuk mendapat nilai kelompok dan kelompok yang dapat mencapai kriteria tertentu bisa mendapatkan sertifikat atau hadiah-hadiah lainnya (Rusman, 2013: 213-214). 
Beberapa penelitian yang telah menunjukkan bahwa model pembelajaran kooperatif tipe STAD dapat meningkatkan hasil belajar dan kerja sama siswa yaitu, penelitian Juneti, dkk pada tahun (2016) bahwa penerapan model pembelajaran STAD dapat meningkatkan hasil belajar IPA siswa. Penelitian lainnya dilakukan oleh Wati pada tahun (2016) menunjukkan bahwa penerapan model pembelajaran STAD dapat meningkatkan kerja sama siswa.

Berdasarkan latar belakang terebut peneliti tertarik untuk melakukan penelitian yang berjudul "Peningkatan Kerja Sama dan Hasil Belajar Ranah CI-C4 Siswa pada Materi Sistem Ekskresi Manusia melalui Model pembelajaran Student Team Achievement Division (STAD) di Kelas VIII C SMP Negeri 2 Srumbung Magelang”. Permasalahan tersebut dirumuskan sebagai berikut: (1) Berapa persen peningkatan keterlaksanaan pembelajaran menggunakan model pembelajaran STAD di kelas VIII C SMP Negeri 2 Srumbung Magelang pada materi sistem ekskresi manusia, (2) berapa persen peningkatan kerja sama siswa menggunakan model pembelajaran STAD di kelas VIII C SMP Negeri 2 Srumbung Magelang pada materi sistem ekskresi manusia, (3) berapa persen peningkatan hasil belajar siswa menggunakan model pembelajaran STAD di kelas VIII C SMP Negeri 2 Srumbung Magelang pada materi sistem ekskresi manusia.

\section{METODE}

Penelitian ini merupakan Penelitian Tindakan Kelas (PTK) yang dilakukan dalam tiga siklus tindakan. Teknik pengumpulan data menggunakan tes dan observasi. Instrumen pengumpulan data menggunakan soal tes dan lembar observasi. Penelitian tindakan kelas meliputi empat tahap yaitu: (1) perencanaan, (2) pelaksanaan, (3) pengamatan dan (4) refleksi. Analisis yang digunakan adalah analisis data deskriptif kuantitatif. Adapun data yang akan dianalisis yaitu soal tes dan lembar observasi.

1. Analisis hasil tes

a. Menghitung nilai rata-rata hasil belajar siswa:

$$
x=\frac{\sum \mathrm{x}}{N}
$$

Keterangan :

X : Nilai rata-rata

$\sum \mathrm{x} \quad$ : Jumlah nilai semua siswa

$\mathrm{N}$ : Banyak siswa yang mengikuti tes

(Sudjana, 2013: 109) 
b. Persentase keberhasilan hasil belajar siswa

Persentase keberhasilan hasil belajar siswa dihitung dengan rumus:

$$
P=\frac{\text { Jumlah siswa yang tuntas }}{\text { Jumlah keseluruhan siswa }} X 100
$$

2. Analisis hasil observasi keterlaksanaan pembelajaran dan kerja sama siswa

Data yang dianalisis yaitu hasil observasi keterlaksanaan pembelajaran dan kerja sama siswa dengan menggunakan rumus sebagai berikut :

$$
N A=\frac{\sum X}{N} X 100 \%
$$

Keterangan:

NA : Nilai akhir

$\sum \mathrm{X} \quad$ : Jumlah keseluruhan skor yang diperoleh

$\mathrm{N} \quad$ : Jumlah keseluruhan skor maksimal

(Djamarah, 2005: 331).

Tabel 1. Kriteria Tingkat Keberhasilan

\begin{tabular}{cc}
\hline Persentase & Kriteria \\
\hline$>80 \%$ & Sangat Tinggi \\
$61-80 \%$ & Tinggi \\
$41-60 \%$ & Sedang \\
$21-40 \%$ & Rendah \\
$<21 \%$ & Sangat rendah \\
\hline
\end{tabular}

(Suharsimi, 2006: 210).

Indikator keberhasilan dalam penelitian ini yaitu: (1) Penelitian dikatakan berhasil apabila $\geq 75 \%$ dari siswa kelas VIII C SMP Negeri 2 Srumbung Magelang mendapatkan nilai rata-rata minimal 75 pada materi sistem ekskresi manusia, sesuai dengan KKM yang telah ditetapkan di SMP Negeri 2 Srumbung Magelang yaitu 75. (2) Penelitian dikatakan berhasil apabila rata-rata persentase indikator kerja sama siswa kelas VIII C SMP Negeri 2 Srumbung Magelang pada lembar observasi mencapai $\geq 75 \%$. 


\section{HASIL DAN PEMBAHASAN}

Berikut ini merupakan data hasil penelitian peningkatan kerja sama dan hasil belajar ranah CI-C4 siswa pada materi sistem ekskresi manusia melalui model pembelajaran Student Team Achievement Division (STAD) di kelas VIII C SMP negeri 2 Srumbung Magelang.

\section{Keterlaksanaan Pembelajaran}

Keterlaksanaan pembelajaran yang meliputi kegiatan guru dan siswa. Berikut ini merupakan hasil observasi keterlaksanaan pembelajaran di kelas VIII C SMP negeri 2 Srumbung Magelang.

Tabel 2. Hasil Keterlaksanaan Pembelajaran

\begin{tabular}{cccc}
\hline No & Siklus & Persentase (\%) & Kriteria \\
& Pembelajaran & & \\
\hline Siklus I & $98,41 \%$ & Sangat Tinggi \\
Siklus II & $100 \%$ & Sangat Tinggi \\
Siklus III & $100 \%$ & Sangat Tinggi \\
\hline
\end{tabular}

Keterlaksanaan pembelajaran menggunakan model pembelajaran STAD pada siklus I diperoleh persentase sebesar 98,41\% dalam kriteria sangat tinggi. Berdasarkan analisis data keterlaksanaan proses pembelajaran ada beberapa langkah-langkah pembelajaran yang belum terlaksana secara optimal yaitu pada indikator (1) guru memberikan motivasi agar siswa dapat belajar dengan baik dan bersungguh-sungguh, dan (2) guru menginformasikan kepada siswa untuk mempelajari materi pada pertemuan berikutnya. Pada indikator tersebut hanya 5 dari 6 observer yang berpendapat setuju. Hal ini dikarenakana guru belum menguasai Rencana Pelaksanaan Pembelajaran (RPP) sehingga ada beberapa langkah-langkah pembelajaran yang belum terlaksana.

Secara umum keterlaksanaan proses pembelajaran dapat dikatakan sudah sangat baik. Akan tetapi pada siklus I ini guru belum dapat mengatur penggunaan waktu dengan tepat sehingga kegiatan diskusi siswa belum tercapai secara optimal. Hal ini karena siswa belum terbiasa belajar menggunakan model pembelajaran STAD, sehingga siswa masih sulit dikondisikan pada saat pembagian kelompok diskusi. Pada saat kegiatan kelompok masih dijumpai siswa yang ramai mengobrol yang tidak berkaitan dengan topik diskusi, sehingga mengganggu jalannya diskusi kelompok.

Keterlaksanaan pembelajaran pada siklus II guru telah melaksanakan pembelajaran sesuai dengan prosedur pembelajaran. Adapun persentase yang diperoleh sebesar 100\% dalam kriteria sangat tinggi. Hal ini dikarenakan guru sudah dapat mengalokasikan waktu dengan baik, siswa sudah paham dengan teknis pembelajaran menggunakan model STAD, 
pada saat kegiatan diskusi kelompok siswa sudah tidak ramai mengobrol dengan temannya sehingga kegiatan diskusi dapat berjalan dengan optimal, siswa merasa lebih senang dan antusias belajar dengan cara berdiskusi.

Berdasarkan analisis data observasi diperoleh persentase keterlaksanaan proses pembelajaran pada siklus III sebesar $100 \%$ dalam kriteria sangat tinggi. Hal ini dikarenakan guru sudah menguasai kelas dengan baik selama proses pembelajaran, siswa lebih akrab dengan guru sehingga siswa sudah tidak merasa canggung. Pembelajaran yang tidak membosankan membuat siswa lebih semangat dan aktif dalam proses pembelajaran.

\section{Kerja Sama Siswa}

Berikut ini merupakan data hasil observasi kerja sama siswa di kelas VIII C SMP negeri 2 Srumbung Magelang.

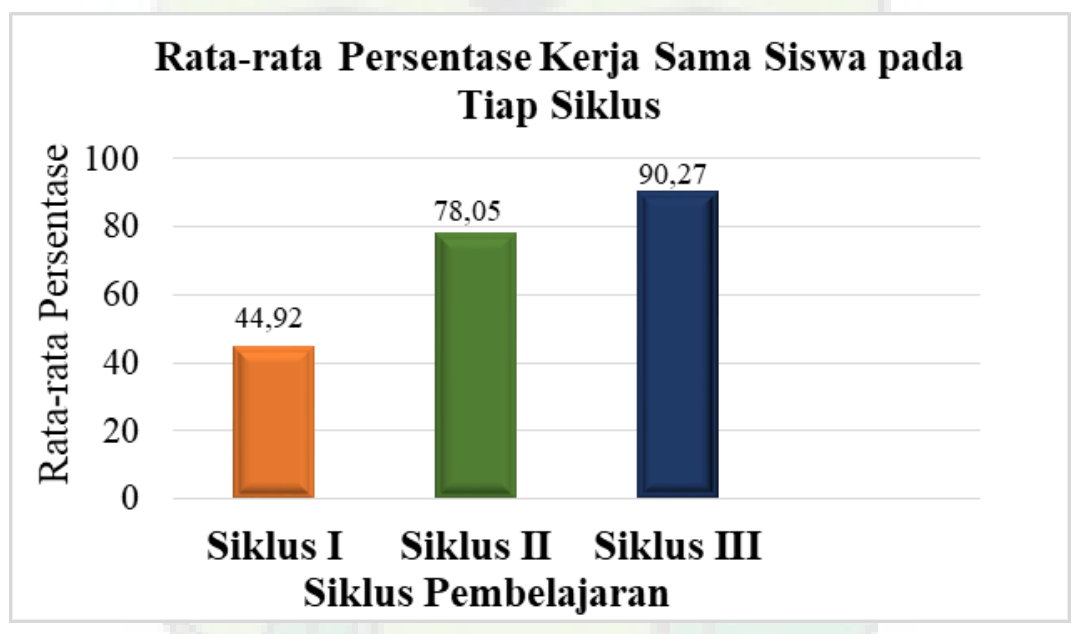

Gambar 1. Perbandingan Persentase Kerja sama Siswa pada Tiap Siklus

Rata-rata persentase kerja sama siswa pada siklus I secara keseluruhan yaitu 44,92\% dalam kriteria sedang. Berdasarkan rata-rata persentase tersebut kerja sama siswa pada siklus I belum mencapai indikator keberhasilan yang ditetapkan. Hal ini dapat disebabkan oleh beberapa faktor diantaranya yaitu siswa belum terbiasa belajar dengan cara berdiskusi, sebagian siswa hanya mengandalkan salah satu anggota kelompok untuk menyelesaikan tugas kelompok dan siswa tidak mau bertanya kepada temannya jika mengalami kesulitan karena takut mendapat respon yang kurang baik. Hal inilah yang mengakibatkan kerja sama siswa dalam kelompok menjadi kurang optimal.

Rata-rata persentase kerja sama siswa pada siklus II secara keseluruhan yaitu 78,05\% dalam kriteria tinggi. Berdasarkan rata-rata persentase tersebut kerja sama siswa pada siklus II sudah mencapai indikator keberhasilan yang ditetapkan. Hal ini dikarenakan siswa saling membantu dalam menyelesaikan tugas, mendengarkan serta menghargai pendapat temannya, 
sehingga dapat dikatakan kerja sama siswa dalam menyelesaikan tugas sudah lebih baik. Kerja sama siswa pada siklus II sudah mencapai indikator keberhasilan yang telah ditetapkan, sehingga penelitian sudah dapat dihentikan pada siklus II. Namun, untuk memastikan kerja sama siswa tetap meningkat atau tidak, maka penelitian dilanjutkan pada siklus III.

Rata-rata persentase kerja sama siswa pada siklus III secara keseluruhan yaitu 90,27\% dalam kriteria sangat tinggi. Berdasarkan rata-rata persentase tersebut kerja sama siswa pada siklus III sudah melampaui indikator keberhasilan yang ditetapkan. Hal tersebut dikarenakan siswa sudah terlibat aktif dalam mengerjakan tugas kelompok, menghargai pendapat temannya dan saling membantu dalam menguasai materi. Hal ini sejalan dengan pendapat yang dikemukakan oleh Hamdayana (2014: 118) bahwa model pembelajaran kooperatif tipe STAD mempunyai keunggulan yang mampu membuat siswa bekerja sama dalam mencapai tujuan, siswa aktif berperan sebagai tutor sebaya untuk lebih meningkatkan keberhasilan kelompok, interaksi antar siswa seiring dengan peningkatan kemampuan mereka dalam berpendapat, meningkatkan kecakapan individu dan meningkatkan kecakapan kelompok.

Hasil Belajar siswa

Data hasil belajar siswa pada materi sistem ekskresi manusia di kelas VIII C SMP Negeri 2 Srumbung Magelang dilihat dari nilai rata-rata dan persentase ketuntasan klasikal yang ditunjukkan oleh Gambar 2 dan 3.

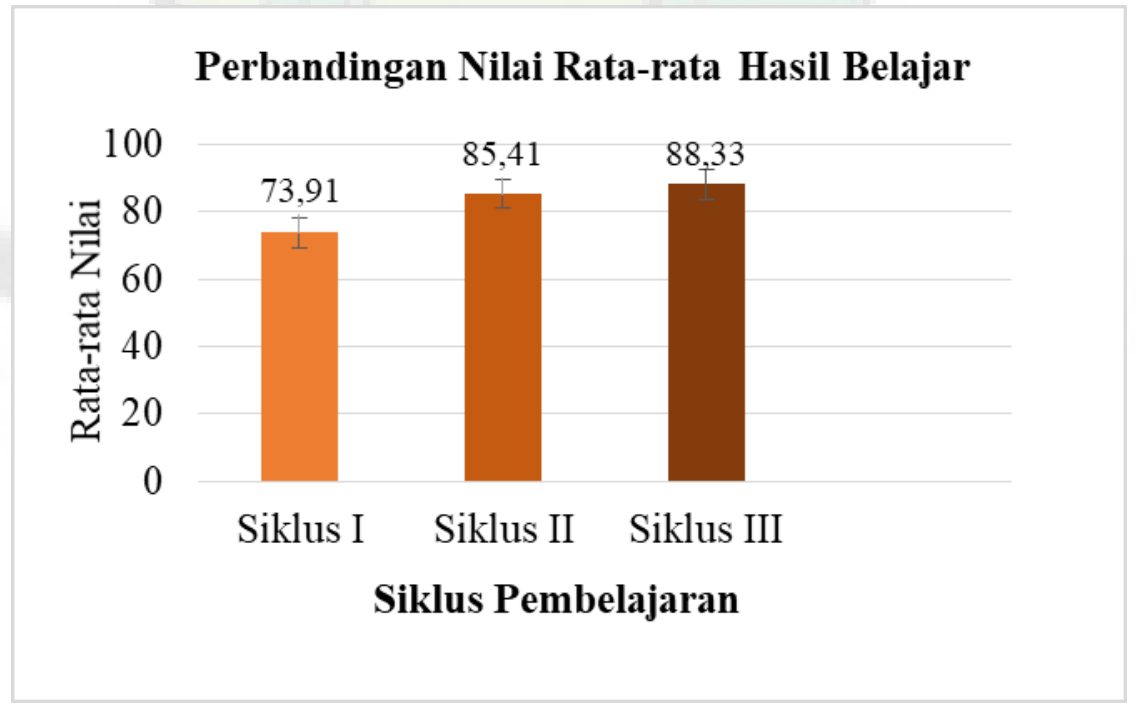

Gambar 2. Diagram Perbandingan Nilai Rata-rata Siswa padaTiap Siklus 


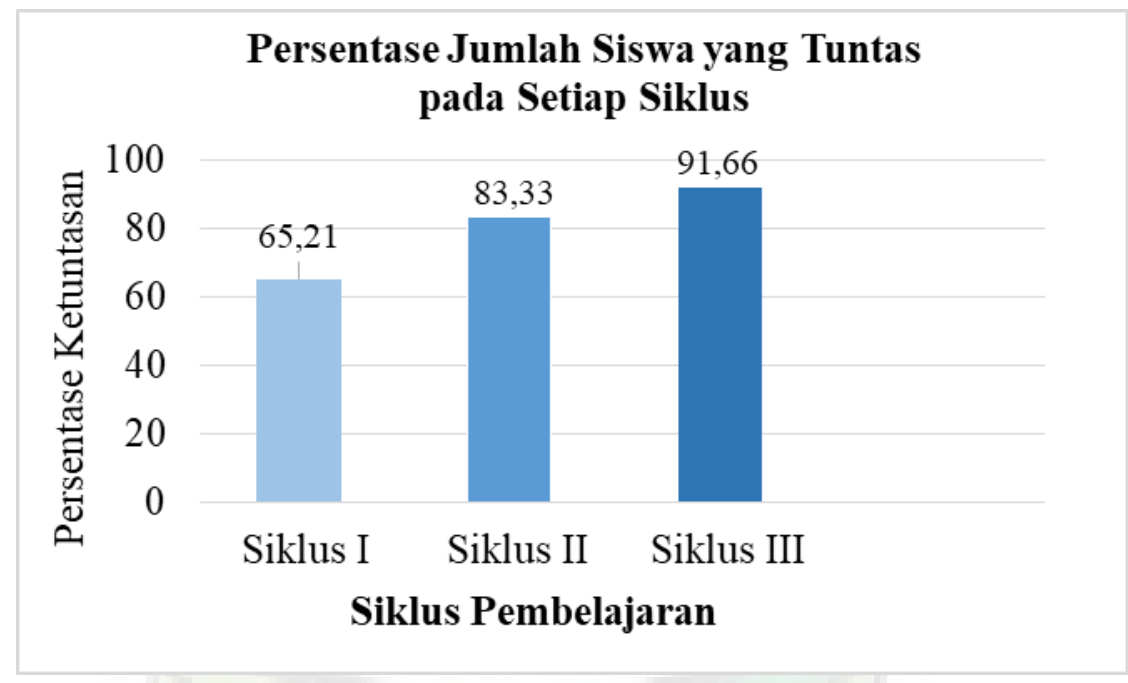

Gambar 3. Diagram Perbandingan Persentase Ketuntasan Siswapada Tiap Siklus

Berdasarkan analisis data hasil belajar pada materi sistem ekskresi manusia melalui model pembelajaran STAD siklus I dapat dilihat pada Gambar 2, bahwa memperoleh nilai rata-rata sebesar 73,91 dalam kriteria tinggi. Akan tetapi hasil belajar pada siklus I tersebut belum mencapai KKM yang ditetapkan oleh sekolah yaitu 75. Berdasarkan data Gambar 3, siswa yang tuntas mendapatkan nilai $>75$ sebanyak 15 siswa dengan persentase $65,21 \%$ dalam kriteria tinggi. Berdasarkan persentase tersebut jumlah siswa yang tuntas belum mencapai indikator keberhasilan yang telah ditetapkan yaitu 75\%. Hal ini dikarenakan siswa belum paham dengan teknis pembelajaran menggunakan model STAD, sehingga pada saat kegiatan pembelajaran siswa masih terlihat bingung. Selain itu siswa kurang memperhatikan pada saat guru menjelaskan sehingga pemahaman siswa terhadap materi masih kurang. Hal tersebut sesuai dengan pernyataan yang diungkapkan oleh Dimyati dan Moedjiono (2009: 254) bahwa siswa yang belum terbiasa dengan penggunaan metode, strategi atau model tertentu dapat berpengaruh terhadap proses belajar yang akan mempengaruhi hasil belajar siswa.

Berdasarkan analisis data pada Gambar 2, diketahui nilai rata-rata siswa sebesar 85,41 dalam kriteria sangat tinggi. Hasil belajar siswa pada siklus II tersebut sudah mencapai KKM yang ditetapkan oleh sekolah yaitu 75. Berdasarkan analisis data pada Gambar 3, siswa yang tuntas mendapatkan nilai > 75 sebanyak 20 siswa dengan persentase sebesar 83,33\% dalam kriteria sangat tinggi. Berdasarkan persentase tersebut jumlah siswa yang tuntas sudah mencapai indikator keberhasilan yang telah ditetapkan yaitu $75 \%$. Hal ini dikarenakan siswa lebih antusias dalam belajar dan memperhatikan pada saat guru menjelaskan, sehingga pemahaman siswa terhadap materi meningkat. Hasil belajar kognitif siswa pada siklus II 
sudah mencapai indikator keberhasilan yang telah ditetapkan, sehingga penelitian sudah dapat dihentikan. Namun, untuk memastikan dan melihat hasil belajar kognitif siswa tetap meningkat atau tidak sekaligus menyelesaikan materi sistem ekskresi manusia, maka penelitian dilanjutkan pada siklus III.

Berdasarkan analisis data pada Gambar 2, nilai rata-rata siswa sebesar 88,33 dalam kriteria sangat tinggi. Hasil belajar pada siklus III sudah melampaui KKM yang ditetapkan oleh sekolah yaitu 75. Berdasarkan data pada Gambar 3, siswa yang tuntas mendapatkan nilai $>75$ sebanyak 22 siswa dengan persentase sebesar 91,66\% dalam kriteria sangat tinggi. Berdasarkan persentase tersebut jumlah siswa yang tuntas sudah mencapai indikator keberhasilan yang telah ditetapkan yaitu $75 \%$. Hal ini dikarenakan siswa lebih tertarik belajar dengan cara berdiskusi karena lebih menyenangkan, melalui diskusi siswa dapat saling membantu dalam menguasai materi, sehingga meningkatkan pemahaman siswa. Hal tersebut sejalan dengan pendapat yang dikemukakan oleh Isjoni (2013: 74) bahwa model pembelajaran kooperatif tipe STAD menekankan adanya aktivitas dan interaksi diantara siswa untuk saling memotivasi dan saling membantu dalam menguasai materi pelajaran untuk mencapai hasil belajar yang maksimal.

\section{SIMPULAN}

Berdasarkan hasil penelitian dan pembahasan, maka dirumuskan kesimpulan sebagai berikut: (1) Penerapan model pembelajaran STAD dapat meningkatkan keterlaksanaan pembelajaran di kelas VIII C SMP Negeri 2 Srumbung Magelang pada materi sistem ekskresi manusia. (2) Penerapan model pembelajaran STAD dapat meningkatkan kerja sama siswa kelas VIII C SMP Negeri 2 Srumbung Magelang pada materi sistem ekskresi manusia. (3) Penerapan model pembelajaran STAD dapat meningkatkan hasil belajar ranah kognitif CI-C4 siswa kelas VIII C SMP Negeri 2 Srumbung Magelang pada materi sistem ekskresi manusia.

\section{REFERENSI}

Apriono, D. 2011. Meningkatkan Keterampilan Kerja Sama Siswa dalam Belajar melalui Pembelajaran Kolaboratif. Jurnal Prospektus, IX (2).

Arikunto, Suharsimi. 2006. Prosedur Penelitian Suatu Pendekatan Praktek. Jakarta: PT. Rineka Cipta.

Dimyati dan Mudjiono. 2009. Belajar dan Pembelajaran. Jakarta: Rineka Cipta.

Djamarah, Syaiful Bahri. 2005. Guru dan Anak Didik dalam Interaksi Edukatif. Jakarta: PT Rineka Cipta. 
Hamdayana, Jumnata. 2014. Model dan Metode Pembelajaran Kreatif dan Berkarakter. Bogor: Ghalia Indonesia.

Isjoni. 2013. Pembelajaran Kooperatif. Yogyakarta: Pustaka Pelajar.

Juneti, Yuslim Fauziah dan Arnentis. 2016. Penerapan Model Pembelajaran Kooperatif Tipe (STAD) untuk Meningkatkan Hasil Belajar IPA Siswa Kelas VII 2 SMPN 6 Tanah Putih Tahun Pelajaran 2015/2016. Jurnal Online Mahasiswa Fakultas Keguruan dan Ilmu Pendidikan Universitas Riau. Vol. 3, No. 2.

Maasavet, E. T. 2011. Meningkatkan Kemampuan Kerja Sama Belajar Biologi Melalui Penerapan Strategi Inkuri Terbimbing pada Siswa Kelas VII SMP Negeri 6 Kota Samarinda. Jurnal Bioedukasi. Vol. 2, No. 1.

Pratiwi, I. A. 2015. Pengembangan Model Kolaborasi Jigsaw Role Playing sebagai Upaya Peningkatan Kemampuan Bekerja Sama Siswa Kelas V SD pada Pelajaran IPS. Jurnal Gusjigang. Vol. 1, No. 2.

Rusman. 2013. Model-model Pembelajaran. Jakarta: Rajawali Press.

Sudjana, Nana. 2013. Penelitian Hasil Proses Belajar Mengajar. Bandung: Rosdakarya.

Suprijono, Agus. 2014. Cooperative Learning. Yogyakarta: Pustaka Pelajar.

Wati, Ida. 2016. Peningkatan Kerja Sama pada Materi Perubahan Benda Menggunakan Model Pembelajaran Cooperative Tipe STAD. Jurnal Penelitian Pendidikan Indonesia. Vol. 1, No. 1. 